\title{
Assessment of intimal tears in thoracic aortic dissection using ECG-gated dual-source computed tomography
}

\author{
Ilona Michałowska ${ }^{1}$, Eugeniusz Szpakowski², Mariusz Furmanek ${ }^{3}$, Mariusz Kuśmierczyk², \\ Tomasz Oleksiuk ${ }^{1}$, Paweł Kwiatek ${ }^{1}$, Hanna Janaszek-Sitkowska ${ }^{4}$, Tomasz Legaszewski ${ }^{5}$, Jacek Różański ${ }^{2}$ \\ ${ }^{1}$ Department of Radiology, Institute of Cardiology, Warsaw \\ 2Department of Cardiac Surgery and Transplantology, Institute of Cardiology, Warsaw \\ ${ }^{3}$ Department of Radiology, Centre for Postgraduate Medical Education, Warsaw \\ ${ }^{4}$ Department of Hypertension, Institute of Cardiology, Warsaw \\ ${ }^{5}$ Department of Radiology, Silesian Medical University, Katowice
}

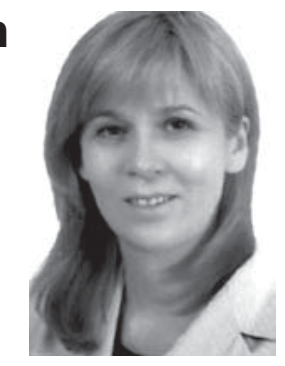

Kardiochirurgia i Torakochirurgia Polska 2013; 10 (2): 171-176

\begin{abstract}
Introduction: Aortic dissection is an acute life-threatening disorder requiring prompt and precise diagnostic imaging. The main role of surgery in type A dissection is the excision of the primary intimal tear, while in the case of endovascular treatment of type B dissection it is the occlusion of the entry tear. The aim of the study was to assess the initial intimal and additional tears within the thoracic aorta using ECG-gated dual-source computed tomography (DSCT).

Material and methods: 53 patients (39 male, mean age 55.69 years) with thoracic aorta dissections were analyzed. The ECG-gated angio-CT was performed using dual-source computed tomography. The presence, location, and measurements of the initial intimal and additional tears in the thoracic aorta were assessed. The CT results were confirmed by surgical reports or by aortographic results in the case of endovascular treatment.

Results: Out of 53 patients, 42 (79.25\%) had type A dissection, and $11(20.75 \%)$ had type B. The initial tear was detected in $98.15 \%$ of patients (in 41 patients with type $A$ and in all patients with type $B$ dissection). There was no significant difference between the size of entry in type $A$ and type $B$ dissection (20.07 vs. $12.2 \mathrm{~mm}, p=0.14$ ). Additional tears were detected in $12(28,5 \%)$ patients with type A dissection but none were found in patients with type $B$ dissection.

Conclusions: ECG-gated DSCT allows for the assessment of the precise location and size of the intimal tear and to find additional tears. The intimal tears in type $A$ and $B$ dissection can be located in the aortic arch. The size of entry in type $A$ and $B$ dissection is comparable. The additional tears in the thoracic aorta are significantly more frequent in the dissection type A. Key words: aorta, dissection, intimal tear.
\end{abstract}

\section{Streszczenie}

Wstęp: Rozwarstwienie aorty jest ostrym stanem aortalnym stanowiącym zagrożenie życia, wymagającym szybkiej i precyzyjnej diagnostyki. Głównym celem leczenia operacyjnego rozwarstwienia typu A jest wycięcie wrót pierwotnych rozwarstwienia, a w przypadku wewnątrznaczyniowego leczenia rozwarstwienia typu B ich zamknięcie. Celem pracy była ocena wrót pierwotnych i wtórnych w aorcie piersiowej przy użyciu dwuźródłowej tomografii komputerowej (DSCT) bramkowanej EKG u pacjentów z rozwarstwieniem aorty piersiowej.

Materiał i metody: Analizie poddano 53 chorych (39 mężczyzn, średnia wieku 55,69 roku) z rozwarstwieniem aorty piersiowej. Bramkowane EKG badania angio-TK aorty wykonywano aparatem dwuźródłowym. Oceniano obecność, lokalizację oraz wielkość wrót pierwotnych oraz występowanie wrót wtórnych w aorcie piersiowej. Obecność i lokalizacja wrót pierwotnych rozwarstwienia była weryfikowana śródoperacyjnie w przypadku pacjentów operowanych lub angiograficznie u pacjentów leczonych wewnątrznaczyniowo.

Wyniki: Rozwarstwienie typu A stwierdzono u 42 chorych (79,25\%), typu B u 11 (20,75\%). Wrota pierwotne uwidoczniono u 98,15\% pacjentów, u 41 z rozwarstwieniem typu A i u wszystkich chorych z typem B rozwarstwienia. Nie stwierdzono istotnej statystycznie różnicy wielkości wrót w grupie A i B rozwarstwienia (20.07 vs $12.2 \mathrm{~mm}, p=0.14$ ). Wtórne wrota rozwarstwienia w aorcie piersiowej wykryto u $12(28,5 \%)$ chorych z rozwarstwieniem typu A; nie stwierdzono wrót wtórnych w aorcie piersiowej u pacjentów z rozwarstwieniem typu B.

Wnioski: DSCT bramkowane EKG pozwala na precyzyjną ocenę lokalizacji i wielkości wrót rozwarstwienia. Wrota pierwotne w obu typach rozwarstwienia mogą być zlokalizowane w łuku aorty. Wielkość wrót w obu typach rozwarstwienia jest podobna. Wrota wtórne w aorcie piersiowej istotnie częściej występują w rozwarstwieniu typu A.

Słowa kluczowe: aorta, rozwarstwienie, wrota rozwarstwienia.

Address for correspondence: dr llona Michałowska, Department of Radiology, Institute of Cardiology, Alpejska 42, 04-628 Warsaw, tel. +48223434168, e-mail: ilonamich@wp.pl 


\section{Introduction}

Aortic dissection is an acute life-threatening disorder requiring prompt and precise diagnostic imaging. The Stanford classification, which is the most widely used system, distinguishes type A dissection (involving the ascending aorta, regardless of the site of the primary intimal tear) and type B dissection (not involving the ascending aorta).

The main role of surgery in the treatment of type A dissection is the excision of the intimal tear. Similarly, in case of endovascular treatment of type B dissection, the primary goal of treatment is the occlusion of the entry tear.

Precise visualization of the primary intimal tear is very important before surgical or endovascular treatment, as it allows preoperative planning and reduction of the duration of surgery.

The most widely used diagnostic method in patients with a suspected acute aortic syndrome (including aortic dissection) is multidetector computed tomography [1]. The specificity and sensitivity of CT in the detection of aortic dissection approaches $100 \%$ [2]. In non-gated angio-CT, pulsation and motion artifacts usually occur in the ascending aorta. They may mimic a dissection or hamper the visualization of the site of the primary intimal tear. Therefore, due to the elimination of cardiac pulsation artifacts, ECG-gated CT is recommended for the evaluation of thoracic aorta dissection [3].

The aim of this study was to assess the presence, location, and measurements of intimal and additional tears in the thoracic aorta using ECG-gated dual-source computed tomography (DSCT) in patients with type A and type B dissection. The CT results were confirmed by surgical reports or by aortographic results in the case of stent graft implantation.

\section{Material and methods}

53 patients with thoracic aortic dissection who underwent angio-CT were analyzed. ECG-gated CT was performed using dual-source CT (Siemens Somatom Definition or Somatom Definition Flash: 39 and 14 patients, respectively). Our protocol of CT examination included non-enhanced acquisition limited to the chest and ECG-gated angiography of the thoracic aorta when the aortic dissection was initially suspected to be limited to the ascending aorta or the aortic arch. In cases in which the dissection was initially suspected to involve the descending part of the aorta, angio-CT of the abdomen and pelvis (to the level of the common iliac arteries) was also performed.

Non-enhanced CT scans allowed detection of intramural hematoma, as well as the presence of blood within the mediastinum, pleura, or pericardium.

DSCT thoracic angiography studies were performed with the use of retrospective ECG gating, $0.6 \mathrm{~mm}$ slice collimation, and 330 or $280 \mathrm{~ms}$ gantry rotation time. The temporal resolution was $83 \mathrm{~ms}$, independently of the heart rate. The tube voltage was set to 120 or $140 \mathrm{kV}$, depending on the patient's body mass. Tube current ranged from 320 to $438 \mathrm{~mA}$. Electrocardiographic dose modulation was used to reduce the radiation dose. Non-ionic contrast material (UItravist 370 Bayer Schering Pharma) was administered into the antecubital vein in the amount of 80-100 $\mathrm{ml}$ (adjusted for individual body weight and scan time) at the flow rate of $5 \mathrm{ml} / \mathrm{s}$. The injection of contrast material was followed by a $30 \mathrm{ml}$ saline flush. Image acquisition was initiated $4 \mathrm{~s}$ after the enhancement threshold of $100 \mathrm{HU}$ was reached within the region of interest in the ascending aorta. In each case, it was possible to start scanning manually. No $\beta$-blockers were administered for heart rate control before the CT examinations.

Post-processing was performed on a dedicated workstation (Leonardo, Siemens Medical Solutions). The presence and location were assessed and the measurements of the intimal tear were performed on multiplanar 2D images.

The primary criterion for the recognition of aortic dissection was the presence of two contrast-filled lumens separated by an intimal flap [4]. The data were analyzed using MedCalc statistical analysis software. Continuous variables are presented as a mean \pm standard deviation (SD) and compared using a two-tailed, unpaired Student's t-test. The two-tailed probability value of $p<0.05$ was considered statistically significant. For accuracy of analysis, dualsource CT findings were compared with available surgical and aortographic findings.

\section{Results}

The baseline characteristics of the patients are provided in Table I.

Out of the 53 patients (39 male, mean age 55.69 years), 42 had type A dissection, and 11 had type B dissection, $p=0.001$. There were 40 acute aortic dissections (symptoms had been present for less than 2 weeks) and 13 chronic dissections (symptoms present for more than 2 weeks).

There were no false positive findings of aortic dissection among the patients treated with surgery or endovascular procedures.

Tab. I. Characteristics of the study population

\begin{tabular}{lc} 
Dates & Numbers \\
Number of patients & 53 \\
\hline Age (years) & $55.7 \pm 13.73$ \\
\hline Gender (male) & $39(73.6 \%)$ \\
\hline Conservative treatment & 14 \\
\hline Surgical treatment & 34 \\
\hline Ascending aorta replacement & 12 \\
\hline Ascending aorta replacement plus partial or & 12 \\
total arch replacement & 10 \\
\hline Bentall procedure & 3 \\
\hline CABG & 5 \\
\hline Stent graft & 7 \\
\hline BAV & 7 (type A ) \\
\hline Death & $39(73.6 \%)$ \\
\hline Hypertension & $40(75.5 \%)$ \\
\hline Hyperlipidemia &
\end{tabular}

BAV - bicuspid aortic valve; CABG - coronary artery bypass graft 
An intimal tear was detected in 52 patients: in 41 type A dissection patients, and in all patients with type B dissection. In one case of type A dissection, the quality of the angio-CT was insufficient to visualize the site of the intimal tear, due to improper enhancement of the aorta in a patient in poor general condition.

In the type A dissection group, the intimal tear was located in the ascending aorta in 35 patients (Fig. 1, 2A, B) (among whom in 12 it was located in the aortic root) and in the aortic arch in 6 patients. In the type B dissection group, the intimal tear was located in the proximal part of the descending aorta in 9 patients (Fig. 3), and in the aortic arch in 2 (Fig. 4).

The average distance from the entry to the aortic annulus in the ascending aorta was $32.85 \pm 21.75 \mathrm{~mm}$. There was no significant difference of the size of entry between the type A and type B dissection groups (20.07 vs. $12.2 \mathrm{~mm}, p=0.14$ ).

Additional tears were detected in the thoracic aorta in 12 patients with dissection type A (28.5\%) (Fig. 5); in 5 patients they were located in the aortic arch, in 5 in the descending aorta, and in 2 cases in the distal part of the ascending aorta.

34 patients were operated on due to type A dissection (3 patients died before surgery, 2 patients refused surgery, and in 3 cases with chronic dissection the surgery risk was too high), 5 patients with dissection type B had an implanted stent graft, and in all cases the dissection was confirmed. The specificity of DSCT in recognizing aortic dissection in patients treated with surgery or endovascular procedures was 100\% (based on 39 patients).

The location of the entry site was confirmed only in 27 (79.4\%) of 34 operated patients; in 6 cases the surgery reports did not include precise information about the entry site, and in one case the intimal tear was not found during surgery. The aortographic results confirmed the entry site

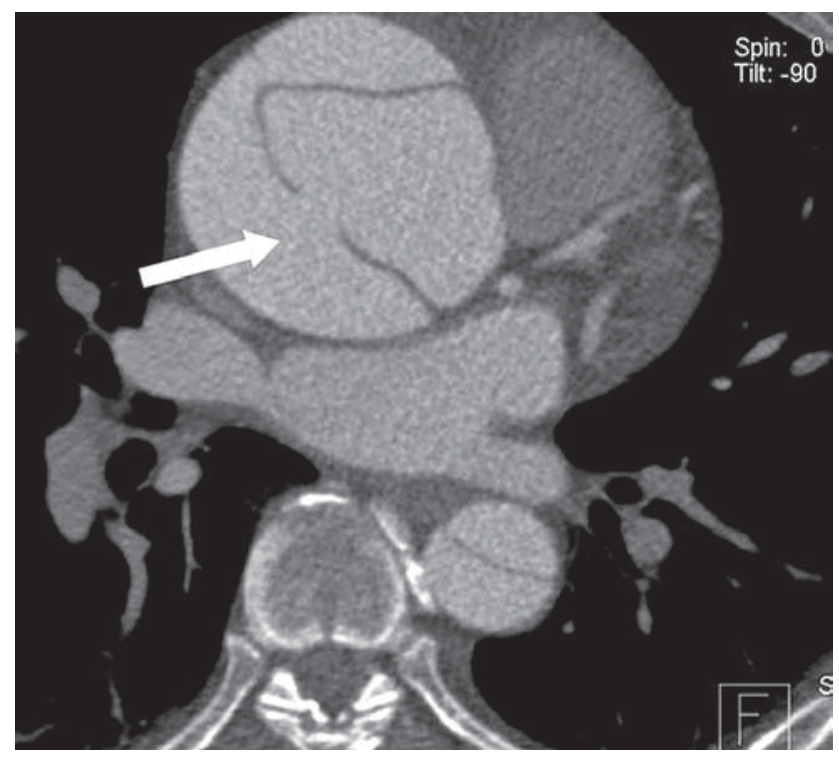

Fig. 1. A 43-year-old male patient with acute aortic dissection (type A). Contrast-enhanced CT axial view shows an intimal tear of the aneurysm of the ascending aorta (arrow)

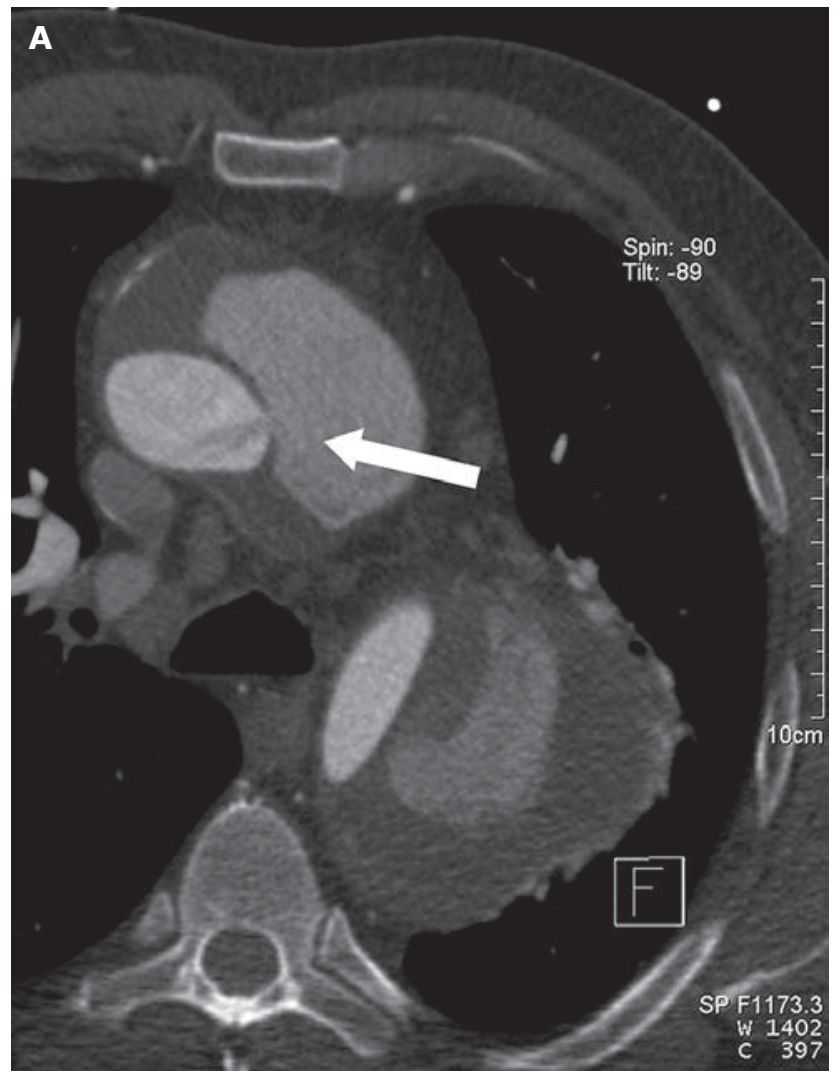

B

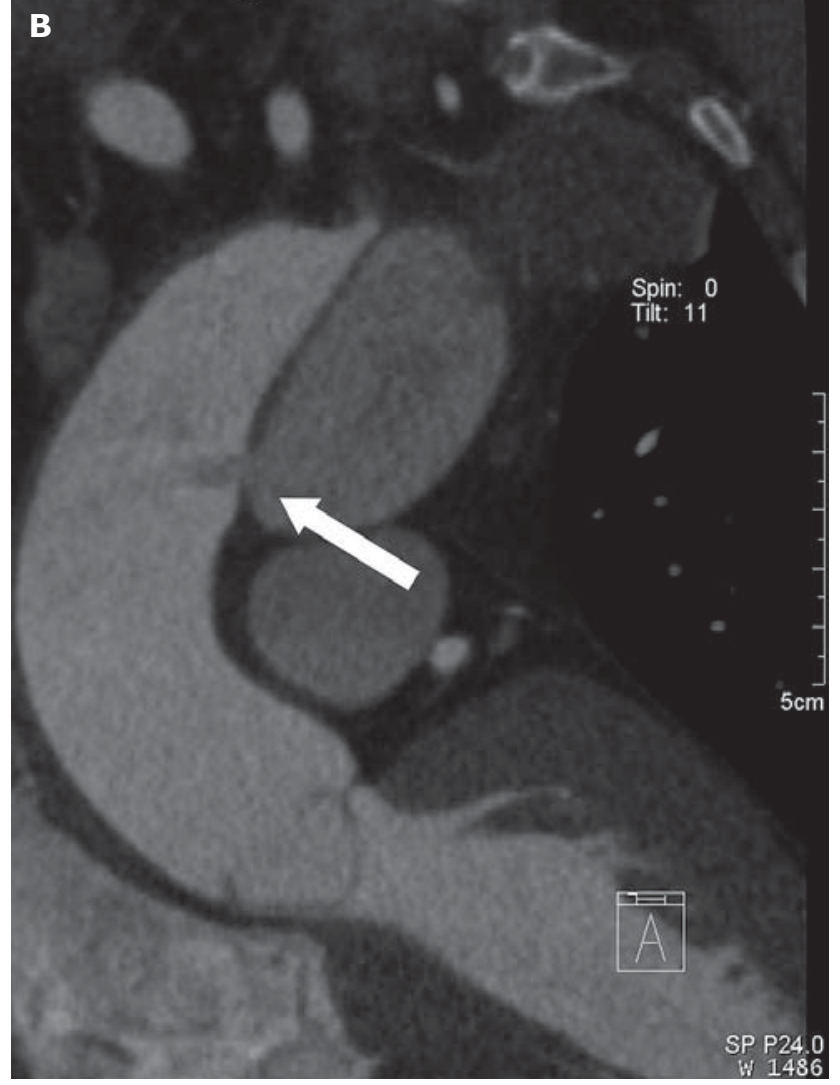

Fig. 2A, B. A 50-year-old male patient with chronic aortic dissection (type A). Contrast-enhanced CT axial (A) and coronal (B) images show an aneurysmal dissection of the thoracic aorta with partial false lumen thrombosis; a small intimal tear is visible in the ascending aorta (arrow) 


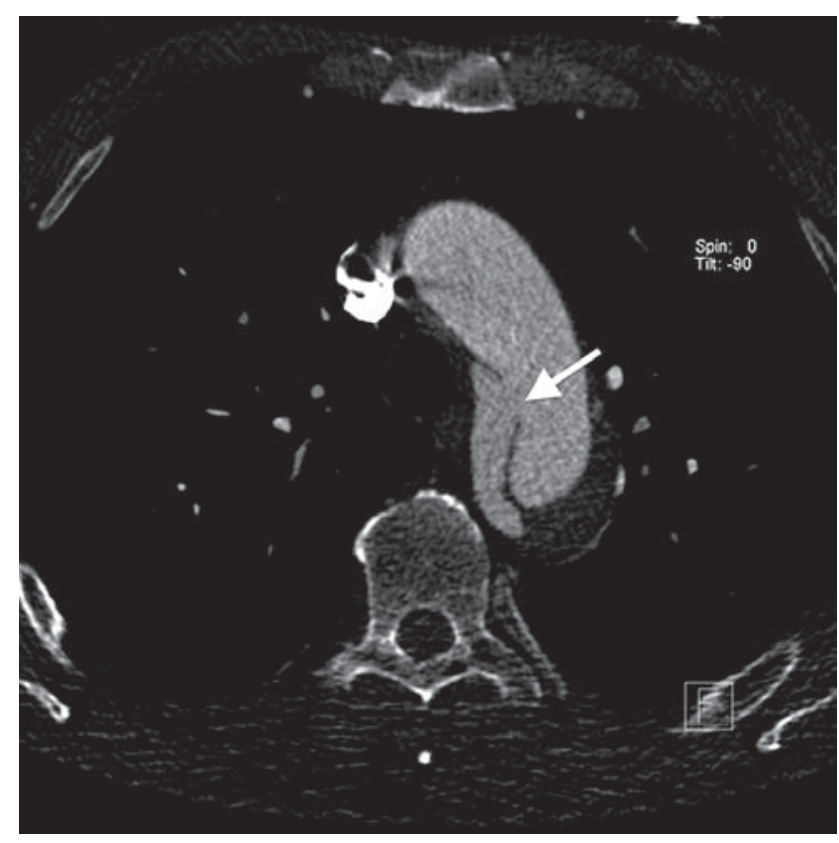

Fig. 3. A 62-year-old male patient with chronic aortic dissection (type B). Contrast-enhanced CT axial view shows an intimal tear in the proximal part of the descending aorta (arrow)

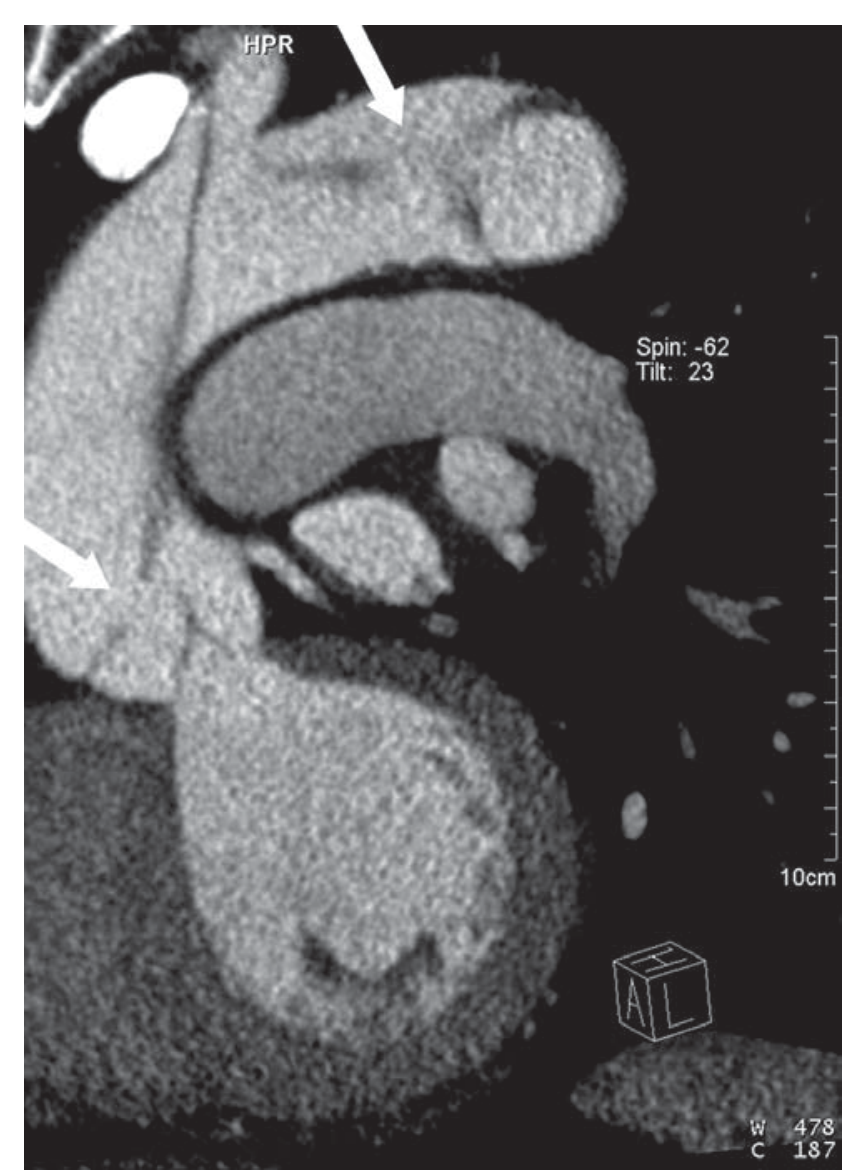

Fig. 5. A 53-year-old male patient with acute aortic dissection (type A). Contrast-enhanced CT coronal view shows an intimal tear in the ascending aorta and an additional tear in the distal part of the arch (arrows)

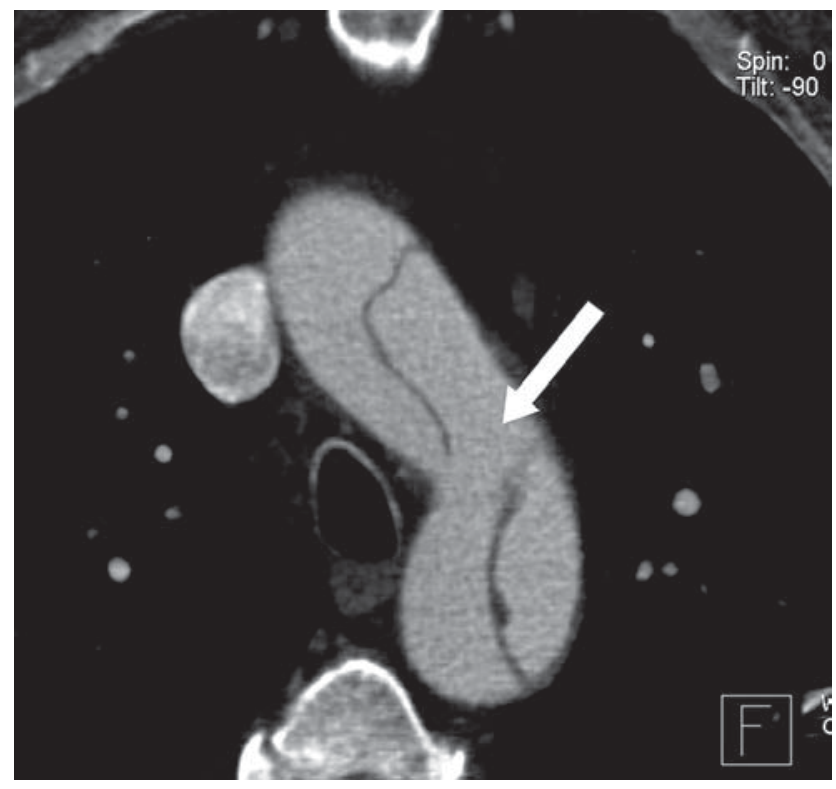

Fig. 4. A 58-year-old-male patient with acute aortic dissection (type B). Contrast-enhanced CT axial view shows an intimal tear in the distal part of the aortic arch (arrow)

in 5 patients, who were treated by endovascular stent-graft implantation.

We found significant differences in the diameter of the sinuses of Valsalva, the tubular portion of the ascending aorta, and the descending aorta between patients with type $A$ and type $B$ dissection; however, there were no significant differences in the diameter of the aortic arch and the abdominal aorta (Table II). The dissection involved the ascending aorta exclusively in 17 cases, the ascending aorta and aortic arch in 7, the thoracic and the abdominal

Tab. II. Comparison of patients with type A and type B dissection

\begin{tabular}{lccc} 
Dissection & Type A & Type B & $p$ \\
Number of patients & $42(79.25 \%)$ & $11(20.75 \%)$ & \\
\hline Gender (male) (\%) & $32(76.2 \%)$ & $7(63.6 \%)$ & 0.001 \\
\hline Age (y) & 54.93 & 58.6364 & 0.43 \\
\hline $\begin{array}{l}\text { Sinuses of Valsalva } \\
\text { (mm) }\end{array}$ & $44.02 \pm 9.21$ & $37.73 \pm 5.83$ & 0.03 \\
\hline $\begin{array}{l}\text { Tubular part of } \\
\text { the ascending } \\
\text { aorta (mm) }\end{array}$ & $54.78 \pm 15.24$ & $42.27 \pm 5.3683$ & 0.01 \\
\hline $\begin{array}{l}\text { Proximal part of } \\
\text { the ascending aorta to } \\
\text { the innominate artery } \\
\text { (mm) }\end{array}$ & $43.36 \pm 10.6$ & $38.1818 \pm 7.05$ & 0.13 \\
\hline Aortic arch (mm) & & & \\
\hline Descending aorta (mm) & $30.55 \pm 6.20$ & $39.07 \pm 6.25$ & 0.02 \\
\hline $\begin{array}{l}\text { Abdominal aorta at } \\
\text { the level of renal arteries } \\
\text { (mm) }\end{array}$ & $24.33 \pm 4.95$ & $25.33 \pm 4.12$ & 0.58 \\
\hline $\begin{array}{l}\text { Chronic dissection } \\
\text { Hypertension }\end{array}$ & $9(21.4 \%)$ & $4(36.4 \%)$ & 0.27 \\
\hline $\begin{array}{l}\text { (m) test of significance } \\
29(69 \%)\end{array}$ & $10(90.9 \%)$ & 0.42 \\
\hline
\end{tabular}

$p$-test of significance 
aorta in 18 cases, and the descending and abdominal aorta in 11 cases.

\section{Discussion}

Acute type A dissection is a life-threatening condition, and many patients die due to aortic rupture, tamponade, malperfusion phenomena, and heart failure secondary to aortic regurgitation or coronary malperfusion [5]. This type of dissection requires urgent surgical intervention. The fundamental strategy of surgical treatment involves the excision of the intimal tear. In most patients, the primary intimal tear is present within the ascending aorta, so ascending aorta or proximal arch replacement is sufficient. When the tear is located in the aortic arch, total or partial arch replacement should be performed to achieve tear excision [6]. If the intimal tear is not resected, the risk of residual aorta enlargement is present [6]. Aortic dissections with persistent false lumens carry high risk of aneurysm formation [7].

Moreover, Bachet et al. [8] reported that the closure of the entry site during the initial emergency operation led to a lower reoperation rate. A remaining patent primary entry tear predicts the need for intervention in patients after surgery for acute type A aortic dissection [9].

Precise information about the location and size of the initial intimal tear and additional tears is important to plan surgery and may influence the extension of surgery. The location of the entry before endovascular treatment is important as well. In the diagnosis of aortic dissection, many imaging modalities are used, including transthoracic echocardiography (TTE), transesophageal echocardiography (TEE), computed tomography (CT) and magnetic resonance imaging (MRI).

Multislice CT with high-resolution volumetric acquisitions and ECG-gating options significantly improved the diagnosis and treatment planning of aortic dissection. The sensitivity and specificity of CT in the detection of acute aortic pathology currently approach $100 \%$ [2], and it is the first-choice imaging procedure for suspected acute aortic diseases.

ECG-gated CT allows for the elimination of cardiac pulsation and motion artifacts, which can obfuscate the proper diagnosis, especially in the area of the ascending aorta, including the sinuses of Valsalva, the valve cusps, and coronary ostia. The artifacts can mimic dissections of the aorta and provide false positive recognition. Motion-free images allow for identification of the site of the primary intimal tear, as well as the location and extent of dissection [10]. The primary intimal tear in type A dissection is located in the ascending aorta in $60-87 \%$ of cases $[10,11]$; in $9 \%$ it is located in the aortic arch, and in $16 \%$ in the isthmus [12], but it may also be located in the descending aorta and propagate retrogradely to the ascending aorta. Pansini et al. [13] intraoperatively detected the site of the intimal tear in the ascending aorta in 233 out of 291 patients, in the aortic arch in 40, and in the descending aorta in 2 cases. Our study showed similar localization of the entry: in $87.5 \%$ of cases it was located in the ascending aorta (including the root), and in $12.5 \%$ in the aortic arch.
We found that $28.5 \%$ of patients with dissection type A had an additional tear in the thoracic aorta, 5 (11.9\%) patients had one in the aortic arch, and 5 had one in the descending aorta.

The detection of additional tears is important because of the possibility of their excision in order to prevent aneurysmal enlargement of the false lumen. Identification of additional entry sites allows for the selection of patients who need an earlier aggressive therapy.

It seems that not only the location of the entry has influence on the prognosis; its size is important as well. Chung et al. [14] concluded that wider intimal tears are associated with a tendency of true lumen collapse and, therefore, with an increased risk of ischemic complications in organs supplied by arteries originating from the true lumen.

Finding large entry tears in the proximal part of the dissection identifies the high-risk subgroup that needs closer followup and can benefit from an earlier aggressive therapy [7].

Quint et al. [11] based their findings on non-gated multislice computed tomography (MSCT) and indicated problems with the recognition and measurements of a tear in the ascending aorta related to motion artifacts; it appears that ECG-gated angio-CT of the thoracic aorta may solve such issues associated with artifacts.

\section{Conclusions}

ECG-gated DSCT allows one to assess the precise location and size of the initial intimal tears and to find additional tears.

The initial intimal tears in type A and B dissection can be located in the aortic arch.

The size of entry in type A and B dissection is comparable. The additional tears occurred more often in type A dissection.

\section{References}

1. Hagan PG, Nienaber CA, Isselbacher EM, Bruckman D, Karavite DJ, Russman PL, Evangelista A, Fattori R, Suzuki T, Oh JK, Moore AG, Malouf JF, Pape LA, Gaca C, Sechtem U, Lenferink S, Deutsch HJ, Diedrichs H, Marcos y Robles J, Llovet A, Gilon D, Das SK, Armstrong WF, Deeb GM, Eagle KA. The International Registry of Acute Aortic Dissection (IRAD): new insights into an old disease. JAMA 2000; 108: 772-778.

2. Hayter RG, Rhea JT, Small A, Tafazoli FS, Novelline RA. Suspected aortic dissection and other aortic disordes:multi-detector row $C T$ in 373 cases in the emergency setting. Radiology 2006; 238: 841-852.

3. Hiratzka LF, Bakris GL, Beckman JA, Bersin RM, Carr VF, Casey DE Jr, Eagle KA, Hermann LK, Isselbacher EM, Kazerooni EA, Kouchoukos NT, Lytle BW, Milewicz DM, Reich DL, Sen S, Shinn JA, Svensson LG, Williams DM; American College of Cardiology Foundation/American Heart Association Task Force on Practice Guidelines; American Association for Thoracic Surgery; American College of Radiology; American Stroke Association; Society of Cardiovascular Anesthesiologists; Society for Cardiovascular Angiography and Interventions; Society of Interventional Radiology; Society of Thoracic Surgeons; Society for Vascular Medicine. 2010 CCF/AHA/AATS/ACR/ASA/SCA/SCAI/SIR/STS/SVM guidelines for the diagnosis and management of patients with Thoracic Aortic Disease: a report of the American College of Cardiology Foundation/American Heart Association Task Force on Practice Guidelines, American Association for Thoracic Surgery, American College of Radiology, American Stroke Association, Society of Cardiovascular Anesthesiologists, Society for Cardiovascular Angiography and Interventions, Society of Interventional Radiology, Society of Thoracic Surgeons, and Society for Vascular Medicine. Circulation 2010; 121: e266-e369. 
4. Cigarroa JE, Isselbacher EM, DeSanctis RW, Eagle KA. Diagnostic imaging in the evaluation of suspected aortic dissection. Old standards and new directions. N Engl J Med 1993; 328: 35-43.

5. Bonser RS, Ranasinghe AM, Loubani M, Evans JD, Thalji NM, Bachet JE, Carrel TP, Czerny M, Di Bartolomeo R, Grabenwöger M, Lonn L, Mestres CA, Schepens MA, Weigang E. Evidence, lack of evidence, controversy, and debate in the provision and performance of the surgery of acute type A aortic dissection. J Am Coll Cardiol 2011; 58: 2455-2474.

6. Unosawa S, Hata M, Niino T, Shimura K, Shiono M. Prognosis of patients undergoing emergency surgery for type $A$ acute aortic dissection without exclusion of the intimal tear. J Thorac Cardiovasc Surg 2012; [Epub].

7. Evangelista A, Salas A, Ribera A, Ferreira-González I, Cuellar H, Pineda V, González-Alujas T, Bijnens B, Permanyer-Miralda G, Garcia-Dorado D. Longterm outcome of aortic dissection with patent false lumen: predictive role of entry tear size and location. Circulation 2012; 125: 3133-3141.

8. Bachet JE, Termignon JL, Dreyfus G, Goudot B, Martinelli L, Piquois A, Brodaty D, Dubois C, Delentdecker P, Guilmet D. Aortic dissection: prevalence, cause and results of late reoperations. J Thorac Cardiovasc Surg 1994; 108: 199-205.
9. Krähenbühl E, Maksimovic S, Sodeck G, Reineke D, Schoenhoff F, Schmidli J, Carrel T, Czerny M. What makes the difference between the natural course of a remaining type $\mathrm{B}$ dissection after type $\mathrm{A}$ repair and a primary type $\mathrm{B}$ aortic dissection? Eur J Cardiothorac Surg 2012; 41: e110-e115.

10. Chin AS, Fleischmann D. State-of-the-art computed tomography angiography of acute aortic syndrome. Semin Ultrasound CT MR 2012; 33: 222-234

11.Quint LE, Platt JF, Sonnad SS, Deeb GM, Williams DM. Aortic intimal tears: detection with spiral computed tomography. J Endovasc Ther 2003; 10: 505-510.

12. Williams DM, Andrews JC, Marx MV, Abrams GD. Creation of reentry tears in aortic dissection by means of percutaneous balloon fenestration: gross anatomic and histologic considerations. J Vasc Interv Radiol 1993; 4: 75-83.

13. Pansini S, Gagliardotto PV, Pompei E, Parisi F, Bardi G, Castenetto E, Orzan F, di Summa M. Early and late risk factors in surgical treatment of acute type A aortic dissection. Ann Thorac Surg 1998; 66: 779-784.

14. Chung JW, Elkins C, Sakai T, Kato N, Vestring T, Semba CP, Slonim SM, Dake MD. True-lumen collapse in aortic dissection: part I. Evaluation of causative factors in phantoms with pulsatile flow. Radiology 2000; 214: 87 